\title{
Acute respiratory failure in kidney transplant recipients: a multicenter study
}

\author{
Emmanuel Canet ${ }^{1}$, David Osman², Jérome Lambert ${ }^{1}$, Christophe Guitton ${ }^{3}$, Anne-Elisabeth Heng ${ }^{4}$, Laurent Argaud ${ }^{5}$, \\ Kada Klouche ${ }^{6}$, Georges Mourad ${ }^{6}$, Christophe Legendre ${ }^{7}$, Jean-François Timsit ${ }^{8}$, Eric Rondeau ${ }^{9}$, \\ Maryvonne Hourmant ${ }^{10}$, Antoine Durrbach ${ }^{11}$, Denis Glotz ${ }^{12}$, Bertrand Souweine ${ }^{4}$, Benoît Schlemmer ${ }^{1}$, \\ Elie Azoulay ${ }^{1 *}$
}

\begin{abstract}
Introduction: Data on pulmonary complications in renal transplant recipients are scarce. The aim of this study was to evaluate acute respiratory failure (ARF) in renal transplant recipients.

Methods: We conducted a retrospective observational study in nine transplant centers of consecutive kidney transplant recipients admitted to the intensive care unit (ICU) for ARF from 2000 to 2008.

Results: Of 6,819 kidney transplant recipients, 452 (6.6\%) required ICU admission, including 200 admitted for ARF. Fifteen (7.5\%) of these patients had combined kidney-pancreas transplantations. The most common causes of ARF were bacterial pneumonia (35.5\%), cardiogenic pulmonary edema (24.5\%) and extrapulmonary acute respiratory distress syndrome (ARDS) (15.5\%). Pneumocystis pneumonia occurred in $11.5 \%$ of patients. Mechanical ventilation was used in 93 patients (46.5\%), vasopressors were used in 82 patients (41\%) and dialysis was administered in 104 patients (52\%). Both the in-hospital and 90-day mortality rates were 22.5\%. Among the 155 day 90 survivors, 115 patients (74.2\%) were dialysis-free, including 75 patients (65.2\%) who recovered prior renal function. Factors independently associated with in-hospital mortality were shock at admission (odds ratio (OR) 8.70, 95\% confidence interval $(95 \% \mathrm{Cl}) 3.25$ to 23.29), opportunistic fungal infection (OR $7.08,95 \% \mathrm{Cl} 2.32$ to 21.60$)$ and bacterial infection (OR 2.53, $95 \% \mathrm{Cl} 1.07$ to 5.96). Five factors were independently associated with day 90 dialysis-free survival: renal Sequential Organ Failure Assessment (SOFA) score on day 1 (OR 0.68/SOFA point, 95\% Cl 0.52 to 0.88), bacterial infection (OR $0.43,95 \% \mathrm{Cl} 0.21$ to 0.90$)$, three or four quadrants involved on chest $\mathrm{X}$-ray (OR $0.44,95 \% \mathrm{Cl} 0.21$ to 0.91), time from hospital to ICU admission (OR 0.98/day, $95 \% \mathrm{Cl} 0.95$ to 0.99 ) and oxygen flow at admission (OR 0.93/liter, $95 \% \mathrm{Cl} 0.86$ to 0.99).
\end{abstract}

Conclusions: In kidney transplant recipients, ARF is associated with high mortality and graft loss rates. Increased Pneumocystis and bacterial prophylaxis might improve these outcomes. Early ICU admission might prevent graft loss.

\section{Introduction}

Kidney transplants account for about two-thirds of all solid organ transplants [1]. In patients with end-stage renal disease, kidney transplantation improves quality of life and overall survival at a lower cost than kidney dialysis [2]. Over the past two decades, the development of new immunosuppressive drugs [3] and advances in the

\footnotetext{
* Correspondence: elie.azoulay@sls.aphp.fr

'Medical Intensive Care Unit and Biostatistics Departments, Saint-Louis

Teaching Hospital, 1 avenue Claude Vellefaux, Paris F-75010, France

Full list of author information is available at the end of the article
}

understanding of drug management and immune modulation have reduced the incidence of acute rejection episodes and have significantly improved long-term outcomes [3-8]. The 10-year graft survival rate is now greater than $60 \%[1,9]$.

These advances have prompted increased use of kidney transplantation and substantial broadening of eligibility criteria for both donors and recipients [10-14]. It has been estimated that in 2006, 103,312 patients were living with a functional renal allograft in the United States [15]. In transplant recipients, long-term

\section{Biomed Central}


exposure to induction and maintenance immunosuppressive therapy used to prevent graft rejection carries a risk of infection, cancer and drug-related toxicities [16-19]. High-dose immunosuppressive therapy for acute rejection episodes significantly increases these lifethreatening complications $[16,19,20]$. Furthermore, in addition to long history of chronic renal disease and dialysis, kidney transplant recipients often have severe comorbidities (for example, cardiovascular disease and diabetes) that are associated with specific immune deficiencies [2]. This combination of problems leads to complications, many of which involve the lungs $[21,22]$. In particular, renal transplant recipients may be at increased risk for acute lung injury (ALI) and acute respiratory distress syndrome (ARDS), most notably in the event of graft failure or antilymphocyte globulin therapy for rejection [23]. Moreover, opportunistic pneumonia is among the leading causes of death in kidney transplant recipients $[24,25]$. Although acute respiratory failure (ARF) compromises short- and longterm outcomes [22], few studies have assessed the need for intensive care unit (ICU) management in kidney transplant recipients with ARF.

The objective of this study was to identify determinants of survival and graft function in kidney transplant recipients admitted to the ICU for ARF. We assessed inhospital mortality and graft function 3 months after ICU discharge $[9,26]$.

\section{Materials and methods}

The ethics committee of the French Society for Critical Care approved this retrospective noninterventional study and waived the need for informed consent. The study was carried out in eight medical ICUs that admit patients from nine transplant centers.

All adult recipients of a kidney or combined kidney and pancreas transplant admitted to the ICU between 1 January 2000 and 1 August 2008 were screened. Among them, we included those admitted for ARF, defined as severe dyspnea at rest, respiratory rate greater than 30 breaths per minute or clinical signs of respiratory distress and oxygen saturation less than $92 \%$ or partial pressure of oxygen in arterial blood less than 60 $\mathrm{mmHg}$ on room air [27].

The data reported in Tables 1,2 and 3 were abstracted from the patients' medical charts. Lifesustaining treatments (that is, noninvasive or invasive mechanical ventilation, renal replacement therapy, vasopressors) were instituted at the discretion of the attending physicians. Criteria for noninvasive and endotracheal mechanical ventilation were also determined by the discretion of the attending physicians.

In all patients, the diagnostic strategy implemented at the time of ICU admission included noninvasive tests (that is, echocardiography, high-resolution computed tomography, blood cultures, sputum examination, urine and serum antigens, polymerase chain reaction assay for cytomegalovirus, and Aspergillus antigenemia) with or without fiberoptic bronchoscopy and bronchoalveolar lavage (FO-BAL) $[28,29]$. The decision to perform FOBAL was at the discretion of the attending physicians.

Disease severity was assessed using the Sequential Organ Failure Assessment (SOFA) score at admission and during the first 3 days in the ICU. Data regarding ICU and hospital lengths of stay, as well as survival status at ICU and hospital discharges and on day 90 after ICU discharge, were available for all patients. Graft survival (that is, patient survival without dialysis) 90 days after ICU discharge was also recorded for survivors.

\section{Statistical analysis}

The statistical results are expressed as medians (25th to 75th percentiles) for quantitative variables or numbers (percentages) for qualitative variables. The characteristics of the patients and ARF episodes were compared between hospital survivors and nonsurvivors using the Wilcoxon rank-sum test or the Fisher's exact test as appropriate. To identify independent predictors of inhospital mortality, baseline characteristics that were statistically significant and clinically relevant were included in a multivariable logistic regression model. A similar analysis was conducted to identify independent predictors of dialysis-free survival 90 days after ICU discharge. Variables entered into both models are listed in Tables 5 and 6 . In both multivariable logistic regression analyses, missing values were imputed via multiple imputations by using chained equations [30]. Log-linear effects of continuous covariates were tested, calibration was tested by using the le Cessie-van Houwelingen goodness-of-fit test [31] and discrimination was assessed by the $C$ index, which is equivalent to the area under the receiver-operating characteristic curve (AUROC) [32]. All tests were two-sided, and $\mathrm{P}<0.05$ was considered statistically significant. Analyses were performed using the R statistical package [33].

\section{Results}

Among the 6,919 patients who received kidney allografts at the nine participating centers during the study period, 452 (6.6\%) were admitted to the ICU, including 216 (47.8\%) admitted for ARF. We report on the 200 patients with no missing data on day 90 (Figure 1).

Patient characteristics are reported in Table 1. Major comorbidities were hypertension (82.8\%), cardiovascular disease (46.7\%) and diabetes (27.6\%). The three leading causes of end-stage renal disease were glomerulonephritis, diabetes mellitus and nephroangiosclerosis. Induction immunosuppressive treatment with antilymphocyte 
Table 1 Patient characteristics ${ }^{\mathrm{a}}$

\begin{tabular}{|c|c|c|c|c|}
\hline Demographics & All patients $(N=200)$ & Hospital survivors $(n=155)$ & Hospital deaths $(n=45)$ & $P$ value \\
\hline Median age, yr (25th to 75 th percentile) & 56 (46 to 65$)$ & 55 (44 to 64$)$ & $61(52$ to 67$)$ & 0.06 \\
\hline Male sex, $n(\%)$ & $123(61.5)$ & $97(62.6)$ & $26(57.8)$ & 0.60 \\
\hline \multicolumn{5}{|l|}{ Comorbidities, $n(\%)$} \\
\hline Hypertension & $164(82.8)$ & $130(85)$ & $35(75.7)$ & 0.18 \\
\hline Heart failure & $93(46.7)$ & $73(47.4)$ & $20(44.4)$ & 0.74 \\
\hline Diabetes mellitus & $55(27.6)$ & $41(26.6)$ & $14(31.1)$ & 0.57 \\
\hline Causes of end-stage renal disease, $n(\%)$ & & & & 0.7 \\
\hline Glomerulonephritis & $52(26)$ & $41(26.5)$ & $11(24.4)$ & \\
\hline Diabetes mellitus & $29(14.5)$ & $21(13.5)$ & $8(17.8)$ & \\
\hline Nephroangiosclerosis & $24(12)$ & $19(12.3)$ & $5(11.1)$ & \\
\hline Polycystic kidney disease & $20(10)$ & $13(8.4)$ & $7(15.6)$ & \\
\hline Uropathy & $14(7)$ & $12(7.7)$ & $2(4.4)$ & \\
\hline Other or undetermined & $61(30.5)$ & $49(31.6)$ & $12(26.7)$ & \\
\hline Characteristics of the transplantation, $n(\%)$ & & & & 0.28 \\
\hline First kidney allograft & $147(73.5)$ & $116(74.8)$ & $31(68.9)$ & \\
\hline Kidney retransplantation & $38(19)$ & $26(16.8)$ & $12(26.7)$ & \\
\hline Combined kidney-pancreas & $15(7.5)$ & $13(8.4)$ & $2(4.4)$ & \\
\hline Cadaver/living donor & 190/8 (96/4) & $148 / 7(95.5 / 4.5)$ & $44 / 1(97.8 / 2.2)$ & 0.69 \\
\hline \multicolumn{5}{|l|}{ Immunosuppressive regimen, $n(\%)$} \\
\hline Cyclosporine & $98(50)$ & $78(51.3)$ & $20(45.5)$ & 0.61 \\
\hline Tacrolimus & $71(36)$ & $54(35.3)$ & $17(38.6)$ & 0.72 \\
\hline Mycophenolate mofetil & $139(71.6)$ & $110(72.8)$ & $29(67.4)$ & 0.57 \\
\hline Sirolimus & $25(12.8)$ & $21(13.9)$ & $4(9.1)$ & 0.61 \\
\hline Azathioprine & $24(12.2)$ & $17(11.2)$ & $7(15.9)$ & 0.44 \\
\hline Steroids & $170(86.7)$ & $132(86.8)$ & $38(86.4)$ & $>0.99$ \\
\hline Acute rejection, $n(\%)$ & $43(21.5)$ & $34(21.9)$ & $9(20)$ & 0.84 \\
\hline Cytomegalovirus disease, $n(\%)$ & $37(19.4)$ & $27(18.4)$ & $10(22.7)$ & 0.52 \\
\hline
\end{tabular}

globulins or basiliximab was used in $94.1 \%$ of patients. At ICU admission, all patients were receiving immunosuppressive therapy, usually with calcineurin inhibitors (86\%) combined with mycophenolate mofetil or azathioprine (83.8\%) and steroids (86.7\%). Forty-three patients $(21.5 \%)$ had a history of acute rejection, which occurred a median of 9.6 months (interquartile range (IQR), 2.4 to 24.8) before ICU admission.

As shown in Table 2, the median time from kidney transplantation to ICU admission was 17 months (IQR, 3 to 67.3). The median time from respiratory symptom onset to ICU admission was 2 days (IQR, 1 to 6 ). At admission, patients were severely hypoxemic with a median of $10 \mathrm{~L} / \mathrm{min}$ oxygen flow (IQR, 6 to 15). Respiratory symptoms included cough in 119 patients (59.8\%), purulent sputum in 31 patients $(15.5 \%)$ and chest pain in 21 patients $(10.5 \%)$. Hemoptysis was noted in six patients (3\%). In addition to ARF, 69 patients (34.8\%) were in shock at ICU admission. Laboratory findings indicated poor graft function at ICU admission, with a median serum creatinine level of $250 \mu \mathrm{M} /(\mathrm{IQR}, 156$ to 382).

FO-BAL was performed in about one-half of the patients $(n=113,56.5 \%)$ and yielded the diagnosis in
$45.5 \%$ of cases. Table 3 reports the clinical features and outcomes according to the cause of ARF. Bacterial pneumonia was the most common diagnosis ( $n=71,35.5 \%)$, with Escherichia coli and Streptococcus pneumoniae being the most often recovered pathogens, but with seven cases of methicillin-resistant Staphylococcus aureus and five cases of Pseudomonas aeruginosa), followed by cardiogenic pulmonary edema $(n=31,24.5 \%)$ and ALI or ARDS related to extrapulmonary bacterial sepsis. Opportunistic fungal infections were diagnosed in 29 patients, including 23 patients with Pneumocystis jirovecii pneumonia, four with invasive aspergillosis, and two with Candidemia. The cause of ARF remained unknown in 25 patients (12.5\%). Table 4 reports the diagnoses of ARF according to time after transplantation. In the early posttransplant period ( $<1$ month), cardiogenic pulmonary edema accounted for nearly one-half of the diagnoses, while opportunistic fungal infections and drug-related pulmonary toxicity were diagnosed mostly in the late posttransplant period (> 6 months).

Noninvasive mechanical ventilation was required in 64 patients (32\%) with $46.9 \%$ success, and invasive mechanical ventilation was required in 93 patients $(46.5 \%)$. 
Table 2 Characteristics of acute respiratory failure ${ }^{a}$

\begin{tabular}{|c|c|c|c|c|}
\hline Patient characteristics & $\begin{array}{l}\text { All patients } \\
(N=200)\end{array}$ & $\begin{array}{l}\text { Hospital survivors } \\
(n=155)\end{array}$ & $\begin{array}{l}\text { Hospital deaths } \\
\quad(n=45)\end{array}$ & $P$ value \\
\hline $\begin{array}{l}\text { Median time from transplantation to ICU admission, months (25th to 75th } \\
\text { percentile) }\end{array}$ & 17 (3 to 67.3$)$ & 17 (2 to 65$)$ & 15 (3 to 98$)$ & 0.69 \\
\hline $\begin{array}{l}\text { Median time from acute rejection to ICU admission, months (25th to } 75 \text { th } \\
\text { percentile) ( } n=43 \text { patients) }\end{array}$ & 9.6 (2.8 to 23.8$)$ & 16.2 (3.6 to 40.8$)$ & $2.4(0.4$ to 7.2$)$ & 0.026 \\
\hline $\begin{array}{l}\text { Median time from dyspnea onset to ICU admission, days (25th to 75th } \\
\text { percentile) }\end{array}$ & $2(1$ to 6$)$ & $2(1$ to 6$)$ & $2(0$ to 7$)$ & 0.97 \\
\hline Median time from hospital to ICU admission, days (25th to 75th percentile) & $3(0$ to 10$)$ & $2(0$ to 9$)$ & $3(0$ to 13$)$ & 0.69 \\
\hline Median body temperature at ICU admission (25th to 75th percentile) & $\begin{array}{l}38.5^{\circ} \mathrm{C}\left(37.2^{\circ} \mathrm{C} \text { to }\right. \\
\left.39.1^{\circ} \mathrm{C}\right)\end{array}$ & $\begin{array}{l}38.5^{\circ} \mathrm{C}\left(37.2^{\circ} \mathrm{C} \text { to }\right. \\
\left.39.1^{\circ} \mathrm{C}\right)\end{array}$ & $\begin{array}{l}38.5^{\circ} \mathrm{C}\left(37.2^{\circ} \mathrm{C} \text { to }\right. \\
\left.39.0^{\circ} \mathrm{C}\right)\end{array}$ & 0.57 \\
\hline $\mathrm{PaO}_{2} / \mathrm{FiO}_{2}$ ratio, $n(\%)$ & & & & 0.14 \\
\hline$>300$ & $19(10.9)$ & $18(13)$ & $1(3)$ & \\
\hline $200-300$ & $47(26.9)$ & $36(27)$ & $11(28)$ & \\
\hline$\leq 200$ & $109(62.3)$ & $81(60)$ & $28(70)$ & \\
\hline ICU admission directly from the emergency room, $n(\%)$ & $61(30.5)$ & $46(30)$ & $15(33)$ & 0.71 \\
\hline Oxygen flow (L/minute) at ICU admission (25th to 75 th percentile) & $10(6$ to 15$)$ & $8(5$ to 15$)$ & $15(6$ to 15$)$ & 0.041 \\
\hline Serum creatinine ( $\mu \mathrm{M} / \mathrm{L})$ at ICU admission (25th to 75 th percentile) & $250(156-382)$ & $255(160-393)$ & $240(150-332)$ & 0.23 \\
\hline Shock at ICU admission, $n$ (\%) & $69(34.8)$ & $40(26)$ & $29(64)$ & $<0.0001$ \\
\hline Need for life-sustaining treatments throughout ICU stay, $n(\%)$ & & & & $<0.0001$ \\
\hline \multicolumn{5}{|l|}{ Respiratory support } \\
\hline Oxygen only & $77(38.5)$ & $75(48)$ & $2(4)$ & \\
\hline NIV & $30(15)$ & $26(17)$ & $4(9)$ & \\
\hline NIV followed by invasive mechanical ventilation & $34(17)$ & $23(15)$ & $11(24)$ & \\
\hline First-line invasive mechanical ventilation & $59(29.5)$ & $31(20)$ & $28(62)$ & \\
\hline Vasopressors & $82(41)$ & $42(27)$ & $40(89)$ & $<0.0001$ \\
\hline Renal replacement therapy & $104(52)$ & $70(45)$ & $34(76)$ & 0.0006 \\
\hline Median SOFA score, day 1 & $7(5$ to 10$)$ & $6(4$ to 8$)$ & 11 (7 to 14$)$ & $<0.0001$ \\
\hline Median SOFA score, day 2 & $6(4$ to 10$)$ & $5(4$ to 7$)$ & $12(7$ to 15$)$ & $<0.0001$ \\
\hline Median SOFA score, day 3 & 5 (4 to 8$)$ & 5 (3 to 6$)$ & $12(7$ to 15$)$ & $<0.0001$ \\
\hline Median length of ICU stay, days & $6(3$ to 12$)$ & $5(3$ to 10$)$ & $8(3$ to 15$)$ & 0.25 \\
\hline Median length of hospital stay, days & $22(13$ to 41$)$ & 22 (14 to 43 ) & 23 (8 to 40$)$ & 0.27 \\
\hline
\end{tabular}

${ }^{\mathrm{a}} \mathrm{ICU}$, intensive care unit; $\mathrm{PaO}_{2} / \mathrm{FiO}_{2}$ ratio, ratio of partial pressure of arterial oxygen to fraction of inspired oxygen; NIV, noninvasive mechanical ventilation; SOFA score, Sequential Organ Failure Assessment score.

Vasopressors were needed in 82 patients (41\%), and renal replacement therapy was administered in 104 patients (52\%).

As shown in Figure 1, ICU mortality was 18\% (36 deaths), and in-hospital mortality was $22.5 \%$ (45 deaths). On day 90 after ICU discharge, all 155 hospital survivors were alive, and among them, 115 patients $(74.2 \%)$ were free of dialysis and 75 patients (65\%) had recovered preICU level of kidney function.

As reported in Table 5, independent determinants of in-hospital mortality were shock at ICU admission (odds ratio (OR) 8.70, 95\% confidence interval (95\% CI) 3.25 to 23.29), diagnosis of opportunistic fungal infection (OR 7.08, 95\% CI 2.32 to 21.60 ) and diagnosis of bacterial infection (OR 2.53, 95\% CI 1.07 to 5.96 ).

Independent determinants of day 90 dialysis-free survival were worse renal SOFA score on day 1 (OR/SOFA point $0.68,95 \%$ CI 0.52 to 0.88 ), diagnosis of bacterial infection (OR $0.43,95 \%$ CI 0.21 to 0.90 ), lung infiltrates in three or more quadrants on chest X-ray (OR 0.44, 95\% CI 0.21 to 0.91 ), longer time from hospital to ICU admission (OR/day $0.98,95 \%$ CI 0.95 to 0.99 ) and oxygen flow at ICU admission (OR per liter $0.93,95 \%$ CI 0.86 to 0.99 ) (Table 6).

\section{Discussion}

We found that $6.6 \%$ of 6,819 kidney transplant recipients from nine transplant centers experienced acute illnesses requiring ICU admission and that the reason for ICU admission was ARF in about one-half of these patients. Data collected 90 days after ICU discharge showed that $22.5 \%$ of patients had died, $20 \%$ had lost their transplant and returned to dialysis, $20 \%$ had experienced deterioration in renal function and only $37.5 \%$ had recovered their pre-ICU renal function. Mortality was associated not only with the severity of the respiratory and hemodynamic manifestations but also with the cause of ARF, with bacterial and fungal 
Table 3 Characteristics of the pulmonary involvement according to the cause of acute respiratory failure ${ }^{a}$

\begin{tabular}{|c|c|c|c|c|c|c|c|c|c|c|}
\hline Cause & $\begin{array}{c}\begin{array}{c}\text { Number } \\
\text { of } \\
\text { patients }\end{array}\end{array}$ & $\begin{array}{c}\text { Time (days) since } \\
\text { respiratory symptoms } \\
\text { onset }\end{array}$ & $\begin{array}{l}\text { ARDS }\left(\mathrm{PaO}^{2} / \mathrm{FiO}^{2} \leq\right. \\
\text { 200) at admission }\end{array}$ & $\begin{array}{c}\text { Lung infiltration } \geq 3 \\
\text { quadrants on chest } X \text { - } \\
\text { ray }\end{array}$ & $\begin{array}{l}\text { Shock at } \\
\text { admission }\end{array}$ & $\begin{array}{l}\text { Mechanical } \\
\text { ventilation }\end{array}$ & $\begin{array}{c}\text { Renal } \\
\text { replacement } \\
\text { therapy }\end{array}$ & Vasopressors & $\begin{array}{l}\text { Hospital } \\
\text { mortality }\end{array}$ & $\begin{array}{c}\text { Day } 90 \\
\text { dialysis-free } \\
\text { survival }\end{array}$ \\
\hline All patients & 200 & $2(1-6)$ & $109(62.3)$ & & 69 (34.8) & $93(47)$ & $82(41)$ & $104(52)$ & $45(22.5)$ & $115(57.5)$ \\
\hline \multicolumn{11}{|l|}{ Bacterial infection } \\
\hline $\begin{array}{l}\text { Bacterial } \\
\text { pneumonia }\end{array}$ & 71 & $2(0-44)$ & $39(62)$ & $27(40)$ & $39(55)$ & $44(62)$ & $43(61)$ & $39(55)$ & $25(35)$ & $33(47)$ \\
\hline $\begin{array}{l}\text { Extrapulmonary } \\
\text { ARDS }\end{array}$ & 31 & $1(0-20)$ & $12(48)$ & $17(57)$ & $18(58)$ & $20(65)$ & $17(55)$ & $19(61)$ & $11(36)$ & $16(52)$ \\
\hline $\begin{array}{l}\text { Cardiogenic } \\
\text { pulmonary edema }\end{array}$ & 49 & $1(0-29)$ & $27(64)$ & $41(85)$ & $7(15)$ & $14(29)$ & $27(55)$ & $11(22)$ & $5(10)$ & $29(59)$ \\
\hline \multicolumn{11}{|l|}{$\begin{array}{l}\text { Opportunistic fungal } \\
\text { infection }\end{array}$} \\
\hline $\begin{array}{l}\text { Pneumocystis } \\
\text { pneumonia }\end{array}$ & 23 & $10(2-44)$ & $18(86)$ & $20(87)$ & $0(0)$ & $12(52)$ & $14(61)$ & $9(39)$ & $7(30)$ & $11(488)$ \\
\hline $\begin{array}{l}\text { Invasive } \\
\text { aspergillosis or } \\
\text { Candidemia }\end{array}$ & 6 & $8(0-45)$ & $1(33)$ & $4(67)$ & $3(50)$ & $5(83)$ & $3(50)$ & $5(83)$ & $5(83)$ & $1(17)$ \\
\hline Viral pneumonia & 6 & $5(2-183)$ & $2(50)$ & $3(60)$ & $0(0)$ & $2(33)$ & $1(17)$ & $0(0)$ & $0(0)$ & $5(83)$ \\
\hline $\begin{array}{l}\text { Drug-related } \\
\text { pulmonary toxicity }\end{array}$ & 6 & $12(1-183)$ & $4(67)$ & $5(83)$ & $1(17)$ & $5(83)$ & $4(67)$ & $3(50)$ & $1(17)$ & $3(50)$ \\
\hline Other & 11 & $1(0-30)$ & $4(36)$ & $3(27)$ & $7(64)$ & $4(36)$ & $4(36)$ & $5(46)$ & $4(36)$ & $6(55)$ \\
\hline Undetermined & 25 & $2(0-8)$ & 14 & $4(17)$ & $5(21)$ & $5(20)$ & $6(24)$ & $6(24)$ & $2(8)$ & $20(80)$ \\
\hline
\end{tabular}

${ }^{a}$ Data are expressed as number (\%) or as median (25th to 75 th percentile) for all patients and minimum-maximum for each diagnosis. A total of 203 diagnoses were made in 176 patients, and 25 patients (13\%) had no diagnosis. ARDS, acute respiratory distress syndrome; $\mathrm{PaO}^{2} / \mathrm{FiO}^{2}$ ratio, ratio of partial pressure of arterial oxygen to fraction of inspired oxygen. 
Table 4 Diagnosis of acute respiratory failure according to the delay between transplantation to ICU admission ${ }^{\text {a }}$

\begin{tabular}{|c|c|c|c|c|c|}
\hline \multirow[t]{2}{*}{ Diagnosis } & \multirow[t]{2}{*}{ Number of patients } & \multicolumn{4}{|c|}{ Time from transplantation to ICU admission } \\
\hline & & $<1$ month & 1 to 3 months & 3 to 6 months & $>6$ months \\
\hline All patients & 200 & $27(14 \%)$ & $30(15 \%)$ & $14(7 \%)$ & $129(65 \%)$ \\
\hline \multicolumn{6}{|l|}{ Bacterial infection } \\
\hline Bacterial pneumonia & 71 & $7(24 \%)$ & $15(39 \%)$ & $3(19 \%)$ & $46(32 \%)$ \\
\hline Extrapulmonary ARDS & 31 & $3(10 \%)$ & $6(15 \%)$ & $4(25 \%)$ & $18(13 \%)$ \\
\hline Cardiogenic pulmonary edema & 49 & $14(48 \%)$ & $7(18 \%)$ & $2(13 \%)$ & $26(18 \%)$ \\
\hline \multicolumn{6}{|l|}{ Opportunistic fungal infection } \\
\hline Pneumocystis pneumonia & 23 & 0 & $3(8 \%)$ & $2(13 \%)$ & $18(13 \%)$ \\
\hline Invasive aspergillosis or Candidemia & 6 & 0 & $2(5 \%)$ & $2(13 \%)$ & $2(1 \%)$ \\
\hline Viral pneumonia & 6 & 0 & $3(8 \%)$ & 0 & $3(2 \%)$ \\
\hline Drug-related pulmonary toxicity & 6 & 0 & $1(3 \%)$ & 0 & $5(4 \%)$ \\
\hline Other & 11 & $2(7 \%)$ & $1(3 \%)$ & 0 & $8(6 \%)$ \\
\hline No diagnosis & 25 & $3(10 \%)$ & $1(3 \%)$ & $3(19 \%)$ & $18(13 \%)$ \\
\hline
\end{tabular}

${ }^{a}$ Data are expressed as number of patients (\%) and number of diagnoses (\%). A total of 25 patients had no diagnosis. The 175 remaining patients had a total of 203 diagnoses. ICU, intensive care unit; ARDS, acute respiratory distress syndrome.

pneumonia being associated with higher mortality rates. Graft loss was associated with ARF severity, bacterial infection and worse renal function at ICU admission. Importantly, later ICU admission after hospital admission was associated with a higher risk of returning to dialysis.

The ICU admission rate in our patients is in agreement with rates reported in previous studies. In a single-center study, the ICU admission rate was $6.4 \%$ [21], and other studies have found rates of up to $25 \%[34,35]$ overall and lower rates of admission for ARDS [23]. These differences may be related to differences in ICU admission criteria and in medical complications. ARF was consistently the leading reason for ICU admission in our study. Among our patients with ARF, one-third required noninvasive mechanical ventilation and nearly one-half required endotracheal ventilation.

Transplant recipients are at increased risk for infection, drug toxicities and cancer [16,20]. Infection is the leading reason for ICU admission and is significantly

Table 5 Multivariable analysis: predictors of in-hospital mortality ${ }^{a}$

\begin{tabular}{lccc}
\hline Predictor of hospital mortality & $\begin{array}{c}\text { Odds } \\
\text { ratio }\end{array}$ & $\begin{array}{c}\mathbf{9 5 \%} \text { confidence } \\
\text { interval }\end{array}$ & $\begin{array}{c}\boldsymbol{P} \\
\text { value }\end{array}$ \\
\hline Shock at ICU admission & 8.70 & 3.25 to 23.29 & 0.00002 \\
$\begin{array}{l}\text { Opportunistic fungal infection } \\
\text { b }\end{array}$ & 7.08 & 2.32 to 21.60 & 0.0007 \\
Bacterial infection & 2.53 & 1.07 to 5.96 & 0.034 \\
$\begin{array}{l}\text { Lung infiltration } \geq 3 \text { quadrants } \\
\text { On chest-X ray }\end{array}$ & 2.50 & 0.98 to 6.37 & 0.051 \\
$\begin{array}{l}\text { Extrapulmonary ARDS } \\
\begin{array}{l}\text { Oxygen flow at ICU admission } \\
\text { (per liter) }\end{array}\end{array}$ & 2.30 & 0.83 to 6.38 & 0.11 \\
\hline
\end{tabular}

${ }^{\mathrm{a}} \mathrm{CU}$, intensive care unit; ARDS, acute respiratory distress syndrome; area under the receiver-operating characteristic curve $=0.83$; Cessie van Houwelingen goodness-of-fit test, $P=0.45$; ${ }^{\mathrm{b}}$ Pneumocystis pneumonia, invasive aspergillosis, or Candidemia. associated with death [36]. ARF is probably most likely to occur in kidney transplant recipients with high levels of immunosuppression, as indicated in our study by the high rate of previous acute rejection (21.5\%), cytomegalovirus disease (18.5\%) and retransplantation (19\%). In our patients, ARF was due to infection in two-thirds of cases, and E. coli and S. pneumoniae were the most often recovered bacteria. However, the noticeable rates of resistant pathogens, such as methicillin-resistant S. aureus and Pseudomonas spp., should be borne in mind when choosing the first-line antibiotic regimen. Factors that increase the risk of resistant organisms include high-level exposure to the healthcare system during dialysis and transplantation-related assessments. Invasive fungal infections were associated with mortality in our study. Candidiasis and aspergillosis are known to be associated with very high mortality rates [24]. $P$. jirovecii pneumonia was the leading cause of opportunistic infection in our

Table 6 Multivariable analysis: predictors of day 90 dialysis-free survival ${ }^{a}$

\begin{tabular}{|c|c|c|c|}
\hline Predictor variable & $\begin{array}{l}\text { Odds } \\
\text { ratio }\end{array}$ & $\begin{array}{l}\text { 95\% confidence } \\
\text { interval }\end{array}$ & $\begin{array}{c}P \\
\text { value }\end{array}$ \\
\hline $\begin{array}{l}\text { Renal SOFA score on day } 1 \text { (per } \\
\text { point on SOFA scale) }\end{array}$ & 0.68 & 0.52 to 0.88 & 0.004 \\
\hline Bacterial infection & 0.43 & 0.21 to 0.90 & 0.025 \\
\hline $\begin{array}{l}\text { Lung infiltration } \geq 3 \text { quadrants on } \\
\text { chest- } X \text { ray }\end{array}$ & 0.44 & 0.21 to 0.91 & 0.027 \\
\hline $\begin{array}{l}\text { Time from hospital to ICU } \\
\text { admission (per day) }\end{array}$ & 0.98 & 0.95 to 0.99 & 0.045 \\
\hline Oxygen flow at admission (per liter) & 0.93 & 0.86 to 0.99 & 0.048 \\
\hline Shock at admission & 0.61 & 0.29 to 1.25 & 0.17 \\
\hline $\begin{array}{l}\text { Sirolimus-based immunosuppressive } \\
\text { regimen }\end{array}$ & 2.26 & 0.79 to 6.50 & 0.13 \\
\hline
\end{tabular}

${ }^{a}$ Area under the receiver-operating characteristic curve $=0.77$; Cessie van Houwelingen goodness-of-fit test, $P=0.25$; SOFA score, Sequential Organ Failure Assessment score; ICU, intensive care unit. 


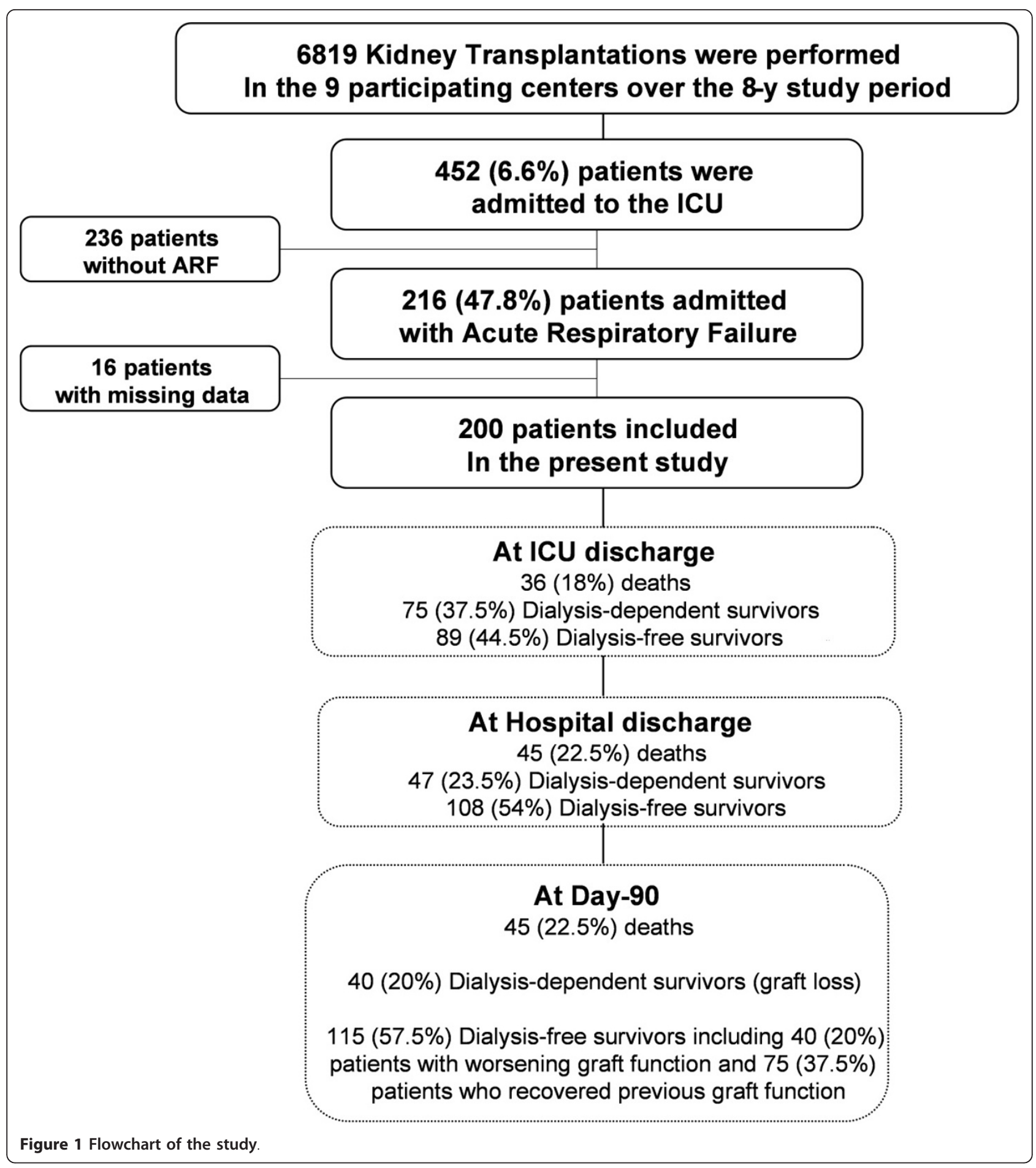

study, despite routine trimethoprim-sulfamethoxazole chemoprophylaxis as recommended [37]. However, $P$. jirovecii pneumonia occurred late after transplantation, at least 6 months after chemoprophylaxis was stopped. This important finding suggests that a longer time on chemoprophylaxis [38] may be appropriate in patients selected on the basis of a history of transplantation, acute rejection episode, pulse and chronic corticosteroid therapy, graft function and immunosuppressive regimen $[25,39]$.

ICU mortality in our cohort was $18 \%$, in keeping with the findings of two earlier studies (10.6\% [35] and 11\% [40]). The 90 -day mortality rate was $22.5 \%$, which was lower than rates reported in earlier studies $[21,22,34,35,40]$. 
Three other studies found substantially higher ICU mortality rates ranging from $36 \%$ to $58.8 \%[21,22,34]$. These differences may be related to several factors. The studies with high mortality rates were single-center studies of small numbers of patients who had greater disease severity at ICU admission and higher SOFA scores (8.6 in the study by Klouche et al. [21]) or greater use of life-sustaining treatments. One study [22] included nosocomial pneumonia occurring during the ICU stay among the causes of ARF, and another [30] included mostly postsurgical patients.

In our study, only $37.5 \%$ of patients recovered their previous level of graft function, and $25.8 \%$ had to resume dialysis. In a single-center study, graft loss requiring resumption of renal replacement therapy was present at ICU discharge in $14.7 \%$ of survivors [21]. In keeping with our results, previous studies found that pre-ICU renal function was a major determinant of graft survival [26] and that ICU admission accelerated the pace of renal function decline [9]. In our study, factors associated with graft loss were worse renal SOFA score at admission, bacterial infection, involvement of more than three quadrants on the chest radiograph and longer time from hospital to ICU admission. The impact of extensive lung infiltrates in our study supports a major role for hypoxemia in loss of graft function. The deleterious impact of later ICU admission on graft survival (but not on patient survival) also deserves attention. Promptness of diagnosis and treatment is crucial to successful treatment [41]. Factors that may contribute to explaining graft loss include bacterial infection with septic shock, cardiogenic edema with a possible alteration from hypertension to hypotension and drug toxicities. Our results support early ICU referral of renal transplant recipients with ARF.

Both FO-BAL and noninvasive tests were useful in identifying the cause of ARF in our study. Immunofluorescence performed on induced sputum yielded the diagnosis of $P$. jirovecii pneumonia in three patients. Blood cultures were often positive as many patients had bacterial pneumonia and ALI or ARDS complicating extrapulmonary (mostly urinary) bacterial infection. Similarly, echocardiography was often informative. The substantial diagnostic yield of FO-BAL supports the first-line use of this procedure until more data on noninvasive tests become available. Also, given the effectiveness of noninvasive tests, we recommend adding them to the standard diagnostic strategy.

Our study has several limitations. First, we used a retrospective design. However, data collection was done specifically for this study and by the same investigator (EC) in the nine centers. Second, we included patients over an 8-year period, during which changes in treatment practices probably occurred. For instance, at ICU admission, $86.7 \%$ of our patients were on corticosteroid therapy. The use of newer immunosuppressive agents such as sirolimus, mycophenolate mofetil, T-cell and B-cell depletion and costimulatory blockade has led to a substantial number of patients being treated without long-term steroid therapy $[6,19]$. Third, one-fourth of our patients had cardiogenic pulmonary edema, in keeping with the high rate of cardiovascular comorbidities. Pulmonary edema does not require invasive diagnostic procedures and differs in its overall management from other causes of ARF. However, cardiogenic pulmonary edema may occur concomitantly with infection. Moreover, the aim of our study was to provide clinicians with data relevant to their everyday practice. Therefore, we included patients with ARF due to cardiogenic pulmonary edema. The strengths of our study include the multicenter design, including nine participating transplant centers, all of which had extensive experience with managing medical complications in kidney transplant recipients. Furthermore, the participating ICUs had considerable experience in managing immunocompromised patients with ARF $[28,42,43]$.

\section{Conclusions}

In summary, medical complications requiring ICU admission occurred in $6.6 \%$ of kidney transplant recipients, and ARF accounted for one-half of these admissions. Bacterial pneumonia, cardiogenic pulmonary edema, and ALI or ARDS related to extrapulmonary sepsis were the leading causes of ARF. Pneumocystis pneumonia was common and severe. By day 90 after ICU discharge, mortality was $22.5 \%, 20 \%$ of the patients had lost their transplant and only $37.5 \%$ of patients had recovered their pre-ICU renal function. Patient survival correlated with acute illness severity and the cause of ARF. Graft survival correlated with previous graft function, pulmonary disease severity and the cause of ARF. Our data suggest that extended chemoprophylaxis for bacterial and fungal infection and early ICU admission of patients with ARF may improve outcomes.

\section{Key messages}

- Acute respiratory failure accounts for one-half of the ICU admissions in recipients of kidney transplantation.

- 90 -day mortality is $22.5 \%$, but a one-fourth of survivors have lost their graft.

- In the early posttransplant period (<1 month) cardiogenic pulmonary edema accounted for one-half of the diagnoses, while opportunistic fungal infections and drug-related pulmonary toxicity were mostly diagnosed in the late posttransplant period $(>6$ months). 
- Fiberoptic bronchoscopy and bronchoalveolar lavage led to the diagnosis in $45.5 \%$ of cases.

- Diagnoses of bacterial or opportunistic fungal infections are associated with in-hospital mortality.

\section{Abbreviations}

ALI: acute lung injury; ARDS: acute respiratory distress syndrome; ARF: acute respiratory failure; FO-BAL: fiberoptic bronchoscopy and bronchoalveolar lavage; ICU: intensive care unit; MV: mechanical ventilation; SOFA: Sequential Organ Failure Assessment.

\section{Acknowledgements}

This work was supported by a grant from the Assistance-Publique Hôpitaux de Paris (AOM 04139) and the French Society for Critical Care.

\section{Author details}

'Medical Intensive Care Unit and Biostatistics Departments, Saint-Louis Teaching Hospital, 1 avenue Claude Vellefaux, Paris F-75010, France. ${ }^{2}$ Medical Intensive Care Unit, Bicêtre Teaching Hospital, 78 rue du Général Leclerc, Kremlin-Bicêtre F-94275, France. ${ }^{3}$ Medical Intensive Care Unit, Hôtel-Dieu Teaching Hospital, Place Alexis Ricordeau, Nantes, 44093, France.

${ }^{4}$ Departments of Intensive Care Medicine, Nephrology and Transplantation, Gabriel Montpied Teaching Hospital, 58 rue Montalembert, Clermont-Ferrand F-63003, France. ${ }^{5}$ Medical Intensive Care Unit, Edouard Herriot Teaching Hospital, 5 Place d'Arsonval, Lyon, 69437, France. ${ }^{6}$ Medical Intensive Care Unit, Nephrology and Transplantation, Lapeyronnie Teaching Hospital, 371 Avenue du doyen Gaston Giraud, Montpellier F-34295, France. 'Department of Nephrology and Transplantation, Necker Teaching Hospital, 149 rue de Sèvres, Paris F-75743, France. ${ }^{8}$ Medical Intensive Care Unit, A. Michallon Teaching Hospital, Avenue de Chantourne, Grenoble F-38043, France. ${ }^{9}$ Department of Nephrology and Transplantation, Tenon Teaching Hospital, 4 Rue de la Chine, Paris F-75970, France. ${ }^{10}$ Department of Nephrology and Transplantation, Hôtel-Dieu Teaching Hospital, Place Alexis Ricordeau, Nantes F-44093, France. ${ }^{11}$ Nephrology and Transplantation, Bicêtre Teaching Hospital, 78 rue du Général Leclerc, Kremlin-Bicêtre F-94275, France. ${ }^{12}$ Department of Nephrology and Transplantation, Saint-Louis Teaching Hospital, 1 avenue Claude Vellefaux, Paris F-75010, France.

\section{Authors' contributions}

EC and EA conceived the study, created its design, collected the data and drafted the manuscript. JL performed the statistical analysis. DO, CG, AEH, $\mathrm{LA}, \mathrm{KK}, \mathrm{GM}, \mathrm{GL}, J F T, E R, M H, A D, D G, B S o$ and BSc participated in collecting the data. All authors read and approved the final manuscript.

\section{Competing interests}

The authors declare that they have no competing interests.

Received: 20 October 2010 Revised: 27 January 2011

Accepted: 8 March 2011 Published: 8 March 2011

\section{References}

1. Sayegh $\mathrm{MH}$, Carpenter CB: Transplantation 50 years later: progress, challenges, and promises. N Engl J Med 2004, 351:2761-2766.

2. Wolfe RA, Ashby VB, Milford EL, Ojo AO, Ettenger RE, Agodoa LY, Held PJ, Port FK: Comparison of mortality in all patients on dialysis, patients on dialysis awaiting transplantation, and recipients of a first cadaveric transplant. N Engl J Med 1999, 341:1725-1730.

3. Kamar N, Garrigue V, Karras A, Mourad G, Lefrançois N, Charpentier B Legendre C, Rostaing L: Impact of early or delayed cyclosporine on delayed graft function in renal transplant recipients: a randomized, multicenter study. Am J Transplant 2006, 6:1042-1048.

4. Mourad G, Karras A, Kamar N, Garrigue V, Legendre C, Lefrançois N, Charpentier B, Bourbigot B, Pouteil-Nobil C, Bayle F, Lebranchu Y, Mariat C, Le Meur Y, Kessler M, Moulin B, Ducloux D, Delahousse M, Lang P, Merville P, Chaouche-Teyara K, Rostaing L, French Myriade FR01 Study Group: Renal function with delayed or immediate cyclosporine microemulsion in combination with enteric-coated mycophenolate sodium and steroids: results of follow up to 30 months post-transplant. Clin Transplant 2007, 21:295-300.
5. Anglicheau D, Legendre C, Thervet E: Pharmacogenetics of tacrolimus and sirolimus in renal transplant patients: from retrospective analyses to prospective studies. Transplant Proc 2007, 39:2142-2144

6. Moore J, Middleton L, Cockwell P, Adu D, Ball S, Little MA, Ready A, Wheatley K, Borrows R: Calcineurin inhibitor sparing with mycophenolate in kidney transplantation: a systematic review and meta-analysis. Transplantation 2009, 87:591-605.

7. Webster A, Pankhurst T, Rinaldi F, Chapman JR, Craig JC: Polyclonal and monoclonal antibodies for treating acute rejection episodes in kidney transplant recipients. Cochrane Database Syst Rev 2006, 2:CD004756.

8. Hariharan S, Johnson CP, Bresnahan BA, Taranto SE, Mclntosh MJ, Stablein D: Improved graft survival after renal transplantation in the United States, 1988 to 1996. N Engl J Med 2000, 342:605-612.

9. Ojo AO, Hanson JA, Wolfe RA, Leichtman AB, Agodoa LY, Port FK: Longterm survival in renal transplant recipients with graft function. Kidney Int 2000, 57:307-313.

10. Andrés $A$, Budde $K$, Clavien PA, Becker $T$, Kessler M, Pisarski $P$, Fornara $P$, Burmeister D, Hené RJ, Cassuto-Viguier E, SENIOR Study Team: A randomized trial comparing renal function in older kidney transplant patients following delayed versus immediate tacrolimus administration. Transplantation 2009, 88:1101-1108.

11. Bayat $S$, Kessler M, Briançon S, Frimat $L$ : Survival of transplanted and dialysed patients in a French region with focus on outcomes in the elderly. Nephrol Dial Transplant 2010, 25:292-300.

12. Martín Navarro J, Ortega M, Gutiérrez MJ, García Martín F, Alcázar JM, Andrés A, Praga M: Survival of patients older than 60 years with kidneys transplanted from Spanish expanded criteria donors versus patients continued on hemodialysis. Transplant Proc 2009, 41:2376-2378.

13. Gavela E, Pallárdo LM, Avila A, Sancho A, Beltrán S, Kanter J, Crespo JF: Renal allografts from donors older than 70 years are useful for single transplantation. Transplant Proc 2009, 41:2047-2049.

14. Moers C, Kornmann NS, Leuvenink HG, Ploeg RJ: The influence of deceased donor age and old-for-old allocation on kidney transplant outcome. Transplantation 2009, 88:542-552.

15. 2009 OPTN/SRTR Annual Report: Transplant Data 1999-2008. [http://optn. transplant.hrsa.gov/ar2009/default.htm].

16. Fishman JA: Infection in solid-organ transplant recipients. N Engl J Med 2007, 357:2601-2614.

17. Jamali FR, Otrock ZK, Soweid AM, Al-Awar GN, Mahfouz RA, Haidar GR, Bazarbachi A: An overview of the pathogenesis and natural history of post-transplant T-cell lymphoma. Leuk Lymphoma 2007, 48:1780-1784.

18. Dantal J, Pohanka E: Malignancies in renal transplantation: an unmet medical need. Nephrol Dial Transplant 2007, 22(Suppl 1):i4-i10.

19. Kahan BD: Fifteen years of clinical studies and clinical practice in renal transplantation: reviewing outcomes with de novo use of sirolimus in combination with cyclosporine. Transplant Proc 2008, 40(10 Suppl): S17-S20.

20. Fishman JA, Rubin $\mathrm{RH}$ : Infection in organ-transplant recipients. $N$ Engl J Med 1998, 338:1741-1751.

21. Klouche K, Amigues L, Massanet P, Garrigue V, Delmas S, Szwarc I Beraud JJ, Mourad G: Outcome of renal transplant recipients admitted to an intensive care unit: a 10-year cohort study. Transplantation 2009, 87:889-895.

22. Candan S, Pirat A, Varol G, Torgay A, Zeyneloglu P, Arslan G: Respiratory problems in renal transplant recipients admitted to intensive care during long-term follow-up. Transplant Proc 2006, 38:1354-1356.

23. Shorr AF, Abbott KC, Agadoa LY: Acute respiratory distress syndrome after kidney transplantation: epidemiology, risk factors, and outcomes. Crit Care Med 2003, 31:1325-1330

24. Sharifipour F, Rezaeetalab F, Naghibi M: Pulmonary fungal infections in kidney transplant recipients: an 8-year study. Transplant Proc 2009, 41:1654-1656.

25. Radisic M, Lattes R, Chapman JF, del Carmen Rial M, Guardia O, Seu F, Gutierrez P, Goldberg J, Casadei DH: Risk factors for Pneumocystis carinii pneumonia in kidney transplant recipients: a case-control study. Transp/ Infect Dis 2003, 5:84-93

26. Kaplan B, Meier-Kriesche HU: Death after graft loss: an important late study endpoint in kidney transplantation. Am J Transplant 2002, 2:970-974.

27. Azoulay E, Mokart D, Lambert J, Lemiale V, Rabbat A, Kouatchet A Vincent F, Gruson D, Bruneel F, Epinette-Branche G, Lafabrie A, Hamidfar- 
Roy R, Cracco C, Renard B, Tonnelier JM, Blot F, Chevret S, Schlemmer B: Diagnostic strategy for hematology and oncology patients with acute respiratory failure: randomized controlled trial. Am J Respir Crit Care Med 2010, 182:1038-1046.

28. Azoulay E, Mokart D, Rabbat A, Pene F, Kouatchet A, Bruneel F, Vincent F, Hamidfar R, Moreau D, Mohammedi I, Epinette G, Beduneau G, Castelain V, de Lassence A, Gruson D, Lemiale V, Renard B, Chevret S, Schlemmer B: Diagnostic bronchoscopy in hematology and oncology patients with acute respiratory failure: prospective multicenter data. Crit Care Med 2008, 36:100-107.

29. Azoulay E, Parrot A, Flahault A, Cesari D, Lecomte I, Roux P, Saidi F, Fartoukh M, Bernaudin JF, Cadranel J, Mayaud C: AIDS-related Pneumocystis carinii pneumonia in the era of adjunctive steroids: implication of BAL neutrophilia. Am J Respir Crit Care Med 1999, 160:493-499

30. Rubin DB, Schenker N: Multiple imputation in health-care databases: an overview and some applications. Stat Med 1991, 10:585-598.

31. Hosmer DW, Hosmer T, Le Cessie S, Lemeshow S: A comparison of goodness-of-fit tests for the logistic regression model. Stat Med 1997, 16:965-980.

32. Harrell FE Jr, Lee KL, Mark DB: Multivariable prognostic models: issues in developing models, evaluating assumptions and adequacy, and measuring and reducing errors. Stat Med 1996, 15:361-387.

33. The R project for Statistical Computing. [http://www.R-project.org].

34. Kirilov D, Cohen J, Shapiro M, Grozovski E, Singer P: The course and outcome of renal transplant recipients admitted to a general intensive care unit. Transplant Proc 2003, 35:606.

35. Kogan A, Singer P, Cohen J, Grozovski E, Grunberg G, Mor E, Shapira Z: Readmission to an intensive care unit following liver and kidney transplantation: a 50-month study. Transplant Proc 1999, 31:1892-1893.

36. Aldawood A: The course and outcome of renal transplant recipients admitted to the intensive care unit at a tertiary hospital in Saudi Arabia. Saudi J Kidney Dis Transpl 2007, 18:536-540.

37. Green H, Paul M, Vidal L, Leibovici L: Prophylaxis for Pneumocystis pneumonia (PCP) in non-HIV immunocompromised patients. Cochrane Database Syst Rev 2007, 3:CD005590.

38. De Castro N, Xu F, Porcher R, Pavie J, Molina JM, Peraldi MN: Pneumocystis jirovecii pneumonia in renal transplant recipients occurring after prophylaxis discontinuation: a case control-study. Clin Microbiol Infect 2009

39. EBPG Expert Group on Renal Transplantation: European best practice guidelines for renal transplantation. Section IV: Long-term management of the transplant recipient. IV.7.1 Late infections. Pneumocystis carinii pneumonia. Nephrol Dial Transplant 2002, 17(Suppl 4):36-39.

40. Sadaghdar $H$, Chelluri $L$, Bowles SA, Shapiro R: Outcome of renal transplant recipients in the ICU. Chest 1995, 107:1402-1405.

41. Tolkoff-Rubin NE, Rubin RH: Opportunistic fungal and bacterial infection in the renal transplant recipient. J Am Soc Nephrol 1992, 2(12 Suppl) S264-S269.

42. Azoulay E, Thiéry G, Chevret $S$, Moreau D, Darmon M, Bergeron A, Yang $K$, Meignin V, Ciroldi M, Le Gall JR, Tazi A, Schlemmer B: The prognosis of acute respiratory failure in critically ill cancer patients. Medicine (Baltimore) 2004, 83:360-370.

43. Barbier F, Coquet I, Legriel S, Pavie J, Darmon M, Mayaux J, Molina JM, Schlemmer B, Azoulay E: Etiologies and outcome of acute respiratory failure in HIV-infected patients. Intensive Care Med 2009, 35:1678-1686.

doi:10.1186/cc10091

Cite this article as: Canet et al: Acute respiratory failure in kidney transplant recipients: a multicenter study. Critical Care 2011 15:R91.

\section{Submit your next manuscript to BioMed Central and take full advantage of:}

- Convenient online submission

- Thorough peer review

- No space constraints or color figure charges

- Immediate publication on acceptance

- Inclusion in PubMed, CAS, Scopus and Google Scholar

- Research which is freely available for redistribution

Submit your manuscript a www.biomedcentral.com/submit 